\title{
THE UTILITARIAN VS. HEDONIC TEACHER ACCEPTANCE OF ICT USE
}

Dr. Pierpaolo LIMONE

ORCID: 0000-0003-3852-4005

Department of Humanities

University of Foggia

Foggia, ITALY

Dr. Maria SINATRA

ORCID: 0000-0002-8099-939X

Department of Educational Sciences

Psychology, Communication, University of Bari

Bari, ITALY

Dr. Giancarlo TANUCCI

ORCID: 0000-0003-4321-9048

Department of Educational Sciences

Psychology, Communication, University of Bari

Bari, ITALY

Dr. Lucia MONACIS

ORCID: 0000-0002-4205-7393

Department of Humanities

University of Foggia

Foggia, ITALY

Received: 18/09/2018 Accepted: 04/04/2019

\begin{abstract}
This research examined which teachers' cognitive and motivational factors, i.e., constructivist beliefs, intrinsic and extrinsic motivation, perceived ease of use and behavioral intention, fostered an effective and satisfactory integration of technology into educational practices. 374 Italian teachers $\left(\mathrm{M}_{\text {Age }}=38.69, \mathrm{SD}=5.30 ; \mathrm{F}=\right.$ 198) attending a training course in ICT were divided into two groups: the first with less than 20 years of teaching experience, the second with more than 21 years. Participants completed a battery of questionnaires that comprised a socio-anagraphic section, the Teacher's Beliefs Scale-Constructivist Teaching, the Intrinsic Motivation-Computer Enjoyment Scale, the Extrinsic Motivation-Perceived Usefulness, the Perceived Ease of Use Scale, the Behavioural Intention to Use Computer Scale, the ICT Class Use Scale. Descriptive and causal analyses (correlation and stepwise regression) were applied to the data. Results showed differences between the groups in the scores of Perceived usefulness and Behavioral intention to use computer. Bivariate associations with Classroom use of technology were strong and positive. Moreover, teachers' Beliefs were strongly related to all motivational factors. Model 5 of regression analysis explained $46.9 \%$ of the variance in ICT Class use and indicated the highest value of Perceived enjoyment, thus highlighting the teachers' hedonic-oriented motivation.
\end{abstract}

Keywords: Teachers, hedonic and utilitarian motivation, ICT integration, constructivist beliefs. 


\section{INTRODUCTION}

The use of Information and Communication Technologies (ICTs) in education has become a relevant and much discussed issue over the last years. Although ICTs provide proactive teaching and active learning, produce knowledge more quickly, and create spaces for interaction and information sharing (Livingstone, 2012), "teachers are a little bit frightened about using of these tools. [...] The teacher is without any training how to use the whiteboard, [...] teachers do not know how to use it and what are its advantages and disadvantages" (Kubiatko, 2017, p. 4). Indeed, the shift from traditional education programs towards technological classrooms has been slow and sporadic. This is why preparing pre-service teachers to integrate technology in their future lessons is urgently needed.

The integration of ICT into the learning environment has been hindered by some obstacles, such as the two types of barriers defined by Ertmer (1999). The first-order barriers, which are extrinsic to teachers and can be removed via governmental policies, refer to the lack of adequate access and time (Legrain, Grillet, Gernigon, \& Lafreniere, 2015; Reddy \& Srivastava, 2003), bandwidth, training and institutional support (e.g., Galanouli, Murphy, \& Gardner, 2004; Ofulue, 2011). Conversely, the second-order barriers are intrinsic to teachers and comprise pedagogical and technology beliefs, and willingness to change (e.g., Inan \& Lowther, 2010; Koehler \& Mishra, 2008; Lane \& Lyle, 2011; Liu \& Szabo, 2009).

As a consequence, a large body of research has focused on how the use of technologies might support teaching practice (Bitonto et al., 2010). In this context, two general categories of professional computer use have been identified (Hogarty, Lang, \& Kromrey, 2003; van Braak, Tondeur, \& Valcke, 2004): the first category, the supportive computer use, is related to the use of computers for pro-active and administrative tasks, like student administration and evaluation, preparing worksheets and keeping track of pupils' learning progress, and the seond category, the class use of computers, concerns the use of computers to support and/ or enhance the teaching or learning process, such as demonstration, drill and practice, instruction, and differentiation. In the current research the interest had been focused on the second category, since a studentcentred class in the learning process has been already promoted.

The influence of personal factors on ICT integration has been also taken into account (e.g., de Palo et al., 2012, 2018; Holden \& Rada, 2011; Kahraman \& Yilmaz, 2018; Teo, 2011) above all in the context of pre-service teachers (Tondeur, Aesaert, Prestridge, \& Consuegra, 2018; Scherer, Tondeur, Siddiq, \& Baran, 2018). But the relationship between motivational factors and cognitive processes, such as teaching constructivist beliefs, teacher self-efficacy, computer self-efficacy, etc., has not been investigated thoroughly (Liu, Lin, \& Zhang, 2017; Sang, Valcke, van Braak, Tondeur, \& Zhu, 2011; Teo, Huang, \& Hoi, 2018), especially when dealing with the linkage between hedonic and utilitarian aspects and constructivist beliefs, and when considering the Italian school contexts (Muscara \& Messina, 2014; Sinatra, Limone, \& Contini, 2017).

One stream of research among motivational models has focused upon Davis' Technology Acceptance Model (TAM; Davis, 1989; Davis, Bagozzi \& Warshaw, 1989), based on the Theory of Reasoned Action (TRA; Fishbein \& Ajzen, 1975). According to the TRA, individuals' behavior is determined by their behavioral intention to perform it. The intention itself is influenced by individuals' attitudes and beliefs towards the behavior. Consequently, the TAM posits that perceived usefulness concerns the degree to which the user believes that using the technology will improve his/her work performance; this component is crucial for technology acceptance. In contrast, perceived ease of use explains how effortless he/she perceives using the technology will be. Indeed, the higher the level of perceived ease of use and perceived usefulness, the higher the tendency to adopt technological innovations; conversely, the lower the management of the benefits produced by innovation, the higher the difficulty of acceptance and use of technology. Both components, i.e., perceived usefulness and perceived enjoyment, might find support in van der Heijden's (2004, p. 696) suggestions on user acceptance of utilitarian vs. hedonic information systems, whose nature affects the importance of perceived usefulness, perceived ease of use and perceived enjoyment in predicting behavioral intention to use the information system. A utilitarian information system is designed to increase the user's task performance while encouraging efficiency; on the contrary, a hedonic, pleasure-oriented system is a function of the degree to which the user experiences fun when using the system. As a consequence, high 
levels of extrinsic motivation, operationalized as perceived usefulness, dominate the first system, high levels of intrinsic motivation, operazionalized as perceived enjoyment, are significant determinants of the second (Fagan, Neill, \& Wooldridge, 2008).

With regard to constructivist beliefs, they have been individualized as a further meaningful factor influencing ICT integration, since they affect teachers' decision-making processes about learning objectives and contents, organizational issues, the selection of media, the choice of instructional strategies, and the adoption of approaches towards assessment and evaluation. In fact, hypothesizing that learning occurs when learners are the makers of knowledge and meaning, the constructivist approach suggests that teachers' beliefs may be strong predictors of class use of computers (Higgins \& Moseley, 2001; Tondeur, van Keer, van Braak, \& Valcke, 2008). This in contrast to the traditional perspective which, assuming that learners receive passively information, may have a negative impact on the integrated ICTuse (Hermans, Tondeur, van Braak, \& Valcke, 2008).

\section{PURPOSE OF THE STUDY}

In light of the above described issues the current research sought to examine which cognitive and motivational factors, i.e., constructivist beliefs, intrinsic and extrinsic motivation, perceived ease of use and behavioral intention, fostered an effective and satisfactory use of technology in educational practices. Given the utilitarian-oriented perspective of this research carried out before a training course, voluntary chosen by teachers to improve their technological performance, it was expected that:

$\boldsymbol{H 1}=$ Behavioural intention to use was the dominant predictor of ICT class use;

$\mathbf{H 2}=$ Following Fishbein and Ajzen's (1975) conceptual framework according to which beliefs can be seen as essential determinants of behavior, constructivist beliefs were stronger than each motivational component;

H3= Perceived usefulness was the strongest predictor of ICT use among motivational components.

\section{METHOD}

\section{Participants}

The sample of this research was recruited from primary and secondary schools of three Italian regions selected on the basis of their convenience and/or accessibility. The sample was composed of 374 teachers $\left(\mathrm{M}_{\text {Age }}=\right.$ $38.69, \mathrm{SD}=5.30 ; \mathrm{F}=198)$ who attended a training course in ICT in the period between November 2017 and January 2018.

\section{Data Collection and Analysis}

The data collection period spanned a week before the beginning of the training course. The teachers participated voluntary and responded to the battery of questionnaires anonymously. The completion of the battery took approximately 20 minutes. The scales were translated into Italian by two authors expert in English and were back translated into English by a native English-speaker.

The methodological approach involved descriptive and causal analyses. As for the descriptive analyses, minimum, maximum, means and standard deviations of each score were calculated. The sample was divided into two groups on the basis of the years of teaching experience, i.e., the first group with less than 20 years $(n=201)$ and the second with more than 21 years $(n=173)$. Mean differences between the two groups were calculated by using independent samples t-test. Bivariate correlations were applied to analyse the associations between the variables of interest. As for the causal analyses, a stepwise linear regression analysis was performed to examine the extent to which constructivist beliefs and motivational factors predicted the didactic use of computers. Age and years of teaching experience were also included. Data analyses were conducted using SPSS 20.0 . 


\section{The Scales}

The battery comprised a socio-anagraphic section (including gender, age, and school category) and five scales:

1. The Teacher's Beliefs Scale - Constructivist Teaching (TBS-CT; Woolley, Benjamin, \& Woolley, 2004) is designed to assess teachers' beliefs related to the student-centred pedagogical perspective (Sang et al., 2011; Tondeur et al., 2008). It is composed of 7 items (e.g., "I involve students in evaluating their own work and setting their own goals"; "I make it a priority in my classroom to give students time to work together when I am not directing them"). The instrument showed a sufficient level of reliability (Cronbach's $\mathrm{a}=.66$ ).

2. The Intrinsic Motivation-Computer Enjoyment Scale (Davis, 1989) measures the extent to which the activity of using the computer is perceived to be enjoyable. The scale comprises 3 items (e.g., "I find using a computer to be enjoyable") and the internal consistency level was high (Cronbach's a $=.91$ ).

3. The Extrinsic Motivation-Perceived Usefulness (Davis, 1989) composed of 6 items assessing the degree to which a person believes that using a particular system would enhance his/her performance (e.g., "Using electronic mail enhances my effectiveness on the job"). The internal consistence was high (Cronbach's $\mathrm{a}=.90$ ).

4. The Perceived Ease of Use Scale (Davis, 1989) is composed of 6 items that assess the degree to which a person believes that using technology would be free of difficulty or effort (e.g., "My interaction with a computer is clear and understandable"). The internal consistency was high (Cronbach's $\mathrm{a}=.88$ ).

5. The Behavioural Intention to Use Computer Scale (Davis, 1989) is composed of 3 items (e.g., "Assuming I had access to a computer, I attend to use it") measuring the likelihood that a person will adopt computer applications. The internal consistency level was high (Cronbach's $\mathrm{a}=.89$ ).

6. The ICT Class Use Scale (ICT-class; van Braak et al., 2004) consists of 8 items (e.g., "I use ICT for independent work/ individual learning") assessing the frequency (from never to daily) of the didactic use of computers in the classroom. The internal consistency level was high (Cronbach's $\mathrm{a}=.83$ ).

All the scales are rated on a 5 -point Likert scale (from $1=$ strongly disagree to $5=$ strongly agree).

\section{FINDINGS}

The results of the descriptive analyses are reported in Table 1.

Table 1. Descriptive statistics: Mean and standard deviation for each variable

\begin{tabular}{lccc}
\hline & Min - Max & Mean & SD \\
\hline Age & $28-57$ & 38.69 & 5.30 \\
Years of teaching experience & $1-41$ & 20.11 & 9.096 \\
TBS-CT & $15-35$ & 28.20 & 2.19 \\
& & & \\
PE & Motivational factors & 12.22 & 2.22 \\
PEU & $3-15$ & 18.83 & 3.47 \\
PU & $6-25$ & 18.10 & 3.02 \\
BIUC & $6-25$ & 12.78 & 1.69 \\
ICT-CU & $8-15$ & 37.25 & 5.17 \\
\hline
\end{tabular}

Note: $T B S-C T=$ Teacher's beliefs scale-Constructivist Teaching; $P E=$ Perceived Enjoyment; $P E U=$ Perceived Ease of Use; $P U=$ Perceived Usefulness; BIUC = Behavioral Intention to Use Computer; ICT-CU = Integration Computer Technology-Classroom Use

No mean differences emerged between the two groups of the teachers in the scores of constructivist beliefs, $\mathrm{t}(372)=1.17, \mathrm{p}=.829$, intrinsic motivation, $\mathrm{t}(372)=.192, \mathrm{p}=.893$, perceived ease of use, $\mathrm{t}(372)=-.204$, 
$\mathrm{p}=.598$ and classroom use of technology, $\mathrm{t}(372)=1.17, \mathrm{p}=.160$. Conversely, differences emerged in the scores of both perceived usefulness, $\mathrm{t}(372)=-.232, \mathrm{p}=.020$, and behavioral intention to use computer, $\mathrm{t}(372)=1.74, \mathrm{p}=.010$. Teachers with less than 20 years of experience obtained higher scores $(\mathrm{M}=20.01, \mathrm{M}$ $=14.01$, respectively) than those of the second group $(\mathrm{M}=18.89, \mathrm{M}=12.58$, respectively).

\section{Correlations}

Findings from bivariate correlations showed a first picture of the interrelationships among the constructs: all associations with the classroom use of technology were strong and positive. Moreover, teachers' constructivist beliefs were strongly related to all motivational factors (Table 2).

Table 2. Bivariate correlations among the variables

\begin{tabular}{cccccc}
\hline & PE & PEU & PU & BIUC & ICT-CU \\
\hline TBS-CT & $.418^{* *}$ & $.336^{* *}$ & $.390^{* *}$ & $.408^{* *}$ & $.534^{* *}$ \\
PE & - & Motivational factors & $.507^{* *}$ \\
PEU & $.573^{* *}$ & $.451^{* *}$ & $-.402^{* *}$ & $.397^{* *}$ & $.490^{* *}$ \\
PU & $.451^{* *}$ & $.402^{* *}$ & - & $.512^{* *}$ & $.472^{* *}$ \\
BIUC & $.397^{* *}$ & $.490^{* *}$ & $.512^{* *}$ & - & $.566^{* *}$ \\
\hline
\end{tabular}

Note: ${ }^{* *} p<.001 ;$ TBS-CT = Teacher's beliefs scale-Constructivist Teaching; PE = Perceived Enjoyment; PEU = Perceived Ease of Use; $P U=$ Perceived Usefulness; BIUC = Behavioral Intention to Use Computer; ICT-CU = Integration Computer Technology-Classroom Use

\section{Regression Analyses}

Five models were created during the stepwise process, adding behavioral intention to use computer, constructivist beliefs, perceived enjoyment, perceived ease of use, and perceived usefulness in decreasing order of their correlation coefficients. As age and years of teaching experience resulted non-significant, they were excluded from the process. Findings indicated that Model 5 explained $46.9 \%$ of the variance in ICT Class use, $\mathrm{F}(5,369)=42.57, \mathrm{p}<.001$. Beta coefficients are reported in Table 3.

Table 3. Regression analyses and standardized beta coefficients

\begin{tabular}{ccccc}
\hline Models & & B & T & Sig. \\
\hline 1 & BIUC & .566 & 9.616 & .000 \\
\hline \multirow{2}{*}{2} & BIUC & .433 & 7.260 & .000 \\
& CBS & .335 & 5.608 & .000 \\
\hline \multirow{2}{*}{3} & BIUC & .368 & 6.094 & .000 \\
& CBS & .266 & 4.385 & .000 \\
\hline \multirow{2}{*}{4} & PE & .225 & 3.688 & .000 \\
\hline & BIUC & .319 & 5.043 & .000 \\
& CBS & .221 & 3.657 & .004 \\
& PE & .195 & 2.898 & .000 \\
& PEU & .162 & 2.373 & .019 \\
\hline & BIUC & .302 & 4.112 & .000 \\
& CBS & .209 & 2.909 & .004 \\
\hline
\end{tabular}




\section{DISCUSSIONS AND CONCLUSION}

The current research sought to analyze the contribution of teacher psychological factors in using ICT in classroom by exploring the extent to which constructivist beliefs, attitudes towards computer, and four motivational components explained the appropriate use of technology in teaching. Overall, findings supported the initial hypotheses except for the third hypothesis related to perceived usefulness. Descriptive results showed differences in years of teaching experience, that is, teachers with more than 21 years of experience seemed to see no need to question or change their professional practice, and thus they were unlikely to adopt the use of ICT in classroom. Compared to teachers with more years of experience, those with less experience seemed to have a positive attitude to the use of ICT in the classroom and to perceive the effectiveness of ICT integration to support both teaching and pupils' learning. This result might be justified by the fact that teachers with more years of experience could not have much formal computer training in their high education, and thus they were more inclined to exhibit a limited use of technological tools. These findings were consistent not only with some investigations showing that ICT use decreases with teaching experience (Bebell, Russell, \& O’Dwyer, 2004; Inan \& Lowther, 2010; van Braak et al., 2004), but also with Prensky's (2001) suggestion that teachers with less experience, being younger and born in a digital world, have been exposed to ICT with more confidence than their counterparts.

Results from bivariate correlations among psychological factors showed that ICT use in classroom was positively linked to constructivist beliefs and motivational factors. Accordingly, teachers with a more studentoriented approach seemed to consider ICT as a useful cognitive tool that encourages students to incorporate their critical-thinking, collaboration, communication, and problem-solving skills into their learning to solve authentic problems. This finding was in line with previous studies that revealed a positive relationship between teachers' beliefs and ICT integration (Deng, Chai, Tsai, \& Lee, 2014; Ertmer, Ottenbreit-Leftwich, \& Tondeur, 2015; Prestridge, 2012).

A careful inspection of the correlation coefficients among constructivist beliefs and the three motivational factors showed the highest value of the first construct, thus supporting the second hypothesis which assumed the determinant role of the beliefs. In addition, the relationship between ICT and behavioral intention to use resulted to be the strongest among the associations with motivational constructs, probably because of the influence of hedonic and utilitarian motivations (i.e., perceived enjoyment and perceived usefulness) on the intentional use. Hence, the first hypothesis formulated in this research was confirmed. This finding obtained in correlational analysis gave empirical evidence for the first hypothesis further confirmed in the casual relationships, i.e., higher levels of willing to use technologies determine their integration in teaching process. This positive effect was found in previous similar research (Liu, Lin, \& Zhang, 2017; Sang et al., 2011; Teo, Huang, \& Hoi, 2018).

When comparing the regression coefficients between utilitarian and hedonistic motivation, the latter yielded a higher value, thus rejecting the third hypothesis. The reason of teachers' hedonic-oriented motivation probably lies in the voluntary - and joyful - attendance of the training course rather than in improving their task performance regardless of what the context may be. As a matter of fact, the coefficient of perceived enjoyment resulted to be close to the value obtained by perceived ease of use. Thereby, it can be said that perceived ease of use played an important role in the hedonic acceptance of ICT use, thus stressing the intention to use it (Ursavaş, 2015). Again, being towards pleasure of functionality, technologies can be conceived through looking at the motivational aspects that drive individuals to manage them.

The research had some limitations. First, as it was performed by two groups of teachers with less and more years of teaching experience, further studies are needed to clarify why teachers' willingness of using ICT tools decreased with experience. A possible explanation

could be related to the fact that compared to digital native teachers, traditional teachers, characterized by a limited use of technological tools, seem to perceived less useful the ICT integration into classroom. Similarly, for teachers with few years of experience should be promoted life long learning courses on technological tools in order to prevent a decrease in ICT integration with the increasing of experience. Second, given that participants' knowledge of computer usage was not explored, the different technological tools were not analyzed, although they could affect the results of the research. For instance, individuals who frequently use the social networking media in their everyday lives have a high chance of accepting technology in their 
teaching and learning (e.g., Elkaseh, Wong, \& Fung, 2016). Third, contents provided by these tools could be not enough adapted and customized to users' needs, cognitive styles, computer attitudes, etc. (e.g., Behera, 2012; Miceli, et al, 2018; Monacis et al., 2016). Consequently, future research should pay more attention to these factors in order to facilitate the human computer interaction and to enhance a successful ICT integration in the classroom (Monacis et al., 2009). Finally, as data in the research were collected by using self-reported questionnaires, which reflected teachers' own evaluation, results could be affected by response bias.

\section{BIODATA and CONTACT ADDRESSES of AUTHORS}

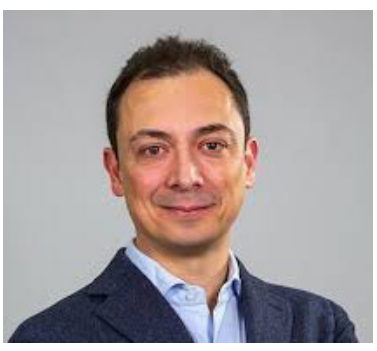

Dr. Pierpaolo LIMONE, is a full professor of Experimental Education and actually the Director of the Department of Humanities at the University of Foggia (Italy). He is also the founder and the director of the laboratory for "Educational Research and Interaction Design" (ERID LAB) at the Department of Humanities which is focused on research projects and services related to digital learning environments. He is an active member in many international associations, such as SIRD (Italian Society of Learning Research), SIPED (Italian Society of Pedagogy), SIe-L (Italian Society of e-Learning) and AERA (American Educational Research Association). He has over 30 articles published in national and international journals and essays submitted to international conferences.

Pierpaolo LIMONE

Address: Department of Humanities

University of Foggia (Italy)

Phone: +39.881 .587641 .

E.mail: pierpaolo.limone@unifg.it

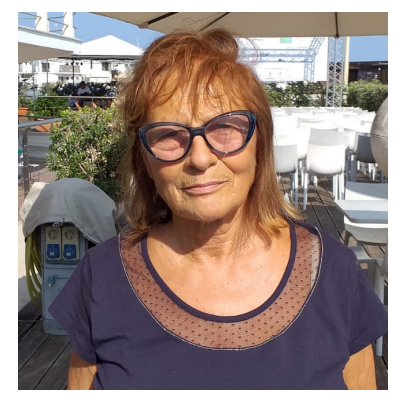

Dr. Maria SINATRA, is a full professor of General psychology at the University of Bari Aldo Moro (Italy). After working at the Johann Wolfgang Goethe University, Frankfurt/Main (Germany), she attended training courses in clinical psychology and family psychotherapy. Currently scientific director of the Centre of Advanced Studies on Cyberpsychology and Ethics, she has been president of the Second Level Degree in Design and Educational Management in Digital Era and Rector's delegate for Counselling at the University of Bari. Her research interests concern the epistemological reconstruction of psychology, as well as open and distance learning, e-learning, and behavioral addictions. On these topics she has published numerous essays in international indexed journals and various books. She is member of various national and international psychological associations.

\section{Maria SINATRA}

Address: Department of Educational Sciences, Psychology, Communication

University of Bari (Italy)

Phone: +39.80 .5717871$

E.mail: maria.sinatra@uniba.it 


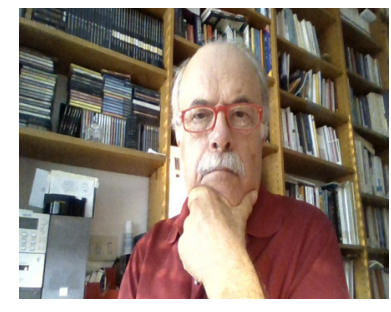

Dr. Giancarlo TANUCCI, is a full professor of Work and Organization Psychology at the University of Bari Aldo Moro (Italy). He carries out teaching and training activities for companies, bodies and institutions on the themes of organizational behavior, evaluation and planning of career paths and on the development of quality. The research fields that characterize the activity of prof. Tanucci concern the area of organizational development and training, selection and assessment of Human Resources, stress management and welfare maintenance factors in organizations. He has served as the Delegate of the Rector of the University of Bari for didactic innovation and university placement. He is a lecturer at the European University of Rome and is a member of national and international scientific and professional associations and works as a consultant for public and private institutions and bodies.

Giancarlo TANUCCI

Address: Department of Educational Sciences, Psychology, Communication

University of Bari (Italy)

Phone: +39.80 .5717871$

E.mail: giancarlo.tanucci@uniba.it

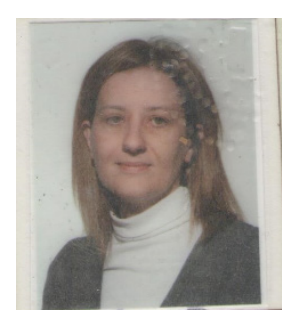

Dr. Lucia MONACIS, is an assistant professor of General psychology at the Department of Humanities of the University of Foggia (Italy). After attending training courses in research methods and specific areas of psychology (personality, testing, etc.) in both Germany and England, she has carried out experimental studies about learning, distance learning, individual differences in teaching/learning, and new technological addictions. On these subjects she has published many articles in indexed national and international journals. She is also an active member in various international associations, is part of the editorial board of various journals, and reviewer of several scientific journals.

Lucia MONACIS

Address: Department of Humanities

University of Foggia (Italy)

Phone: +39.881 .587605$

E.mail: lucia.monacis@unifg.it

\section{REFERENCES}

Bebell, D., Russell, M., \& O’Dwyer, L. (2004). Measuring teachers' technology uses: Why multiple measures are more revealing. Journal of Research on Technology in Education, 37(1), 45-63.

Behera, S. K. (2012). An Investigation into the Attitude of College Teachers towards E-Learning in Purulia District of West Bengal, India. Turkish Online Journal of Distance Education (TOJDE), 13(3), 152-160.

Bitonto, P. D., Roselli, T., Rossano, V., Monacis, L., \& Sinatra, M. (2010). MoMAt: A mobile museum adaptive tour. $\sigma^{\text {th }}$ IEEE International Conference on Wireless, Mobile and Ubiquitous Technologies in Education. Mobile Social Media for Learning and Education in Formal and Informal Settings (WMUTE 2010), (Art. No. 5476554, pp. 156-16). Kaohsiung, Taiwan.

Davis, F. D. (1989). Perceived usefulness, perceived ease of use, and user acceptance of information technology. MIS Quarterly, 13(3), 319-339. doi: 10.2307/249008.

Davis, F. D., Bagozzi, R. P., \& Warshaw, P. R. (1989). User acceptance of computer technology: A comparison of two theoretical models. Management Science, 35(8), 982-1003. doi: 10.1287/mnsc.35.8.982.

Deng, F., Chai, C. S., Tsai, C., \& Lee, M. (2014). The relationship among Chinese practicing teachers' epistemic beliefs, pedagogical beliefs, and their beliefs about the use of ICT. Educational Technology \& Society, 1(2), 245-25.

de Palo, V., Sinatra, M., Tanucci, G., Monacis, L., Di Bitonto, P., Roselli, T., Rossano, V. (2012). How cognitive styles affect the e-learning process. Proceedings of the 12th IEEE International Conference on Advanced Learning Technologies (ICALT 2012), (Art. No. 6268119, pp. 359-363). 
de Palo, V., Limone, P., Monacis, L., Ceglie, F., \& Sinatra, M. (2018). Enhancing e-learning in old age. Australian Journal of Adult Learning, 58 (1), pp. 88-109.

Elkaseh, A. M., Wong, K. W., \& Fung, C. C. (2016). Perceived Ease of Use and Perceived Usefulness of Social Media for e-Learning in Libyan Higher Education: A Structural Equation Modeling Analysis. International Journal of Information and Education Technology, 6(3), 192-199. doi: 10.7763/IJIET.2016.V6.683

Ertmer, P. A. (1999). Addressing first- and second-order barriers to change: strategies for technology integration. Educational Technology Research and Development, 47(4), 47-61. doi: 10.1007/ BF02299597

Ertmer, P. A., Ottenbreit-Leftwich, A. T., \& Tondeur, J. (2015). Teachers' beliefs and uses of technology to support 21st century teaching and learning. In H. Fives \& M. G. Gill (Eds.), International Handbook of Research on Teachers' Beliefs (pp. 403-418). New York: Routledge.

Fagan, M. H., Neill, S., \& Wooldridge, B. R. (2008). An empirical investigation into the relationship between computer self-efficacy, anxiety, experience, support and usage. Journal of Computer Information Systems, 44(2), 95-104.

Fishbein, M., \& Ajzen, I. (1975). Belief, Attitude, Intention, and Behavior: An Introduction to Theory and Research. Reading, MA: Addison-Wesley.

Galanouli, D., Murphy, C., \& Gardner, J. (2004). Teachers' perceptions of the effectiveness of ICT-competence training. Computers \& Education, 43(1-2), 63-79. doi: 10.1016/j.compedu.2003.12.005

Hermans, R., Tondeur, J., van Braak, J., \& Valcke, M. (2008). The impact of primary school teachers' educational beliefs on the classroom use of computers. Computers \& Education, 51(4), 1499-1509. doi: 10.1016/j.compedu.2008.02.001

Higgins, S., \& Moseley, D. (2001). Teachers' thinking about information and communications technology and learning: beliefs and outcomes. Teacher Development, 5(2), 191-210. doi: $10.1080 / 13664530100200138$

Hogarty, K. Y., Lang, T. R., \& Kromrey, J. D. (2003). Another look at technology use in classrooms: the development and validation of an instrument to measure teachers' perceptions. Educational and Psychological Measurement, 63(1), 139-162. doi: 10.1177/0013164402239322

Inan, F. A., \& Lowther, D. L. (2010). Factors affecting technology integration in K-12 classrooms: A path model. Educational Technology Research and Development, 58(2), 137-154. doi: 10.1007/s11423009- 9132-y.

Kahraman, S., Yilmaz, Z. A. (2018). In-service teachers' internet self-efficacy: A re-examination of gender differences. Turkish Online Journal of Distance Education (TOJDE), 19(2), 72-85. doi: 10.17718/ tojde. 415675

Koehler, M. J., \& Mishra, P. (2008). Introducing TPACK. In AACTE Committee on Innovation and Technology (Ed.), Handbook of technological pedagogical content knowledge for educators (pp. 3-29). New York, NY: Routledge.

Kubiatko, M. (2017). Are ICT being used correctly? Small reflection about correct using of ICT in education. Problems of Education in the 21st Century, 75(1), 4-5.

Lane, C. A., \& Lyle, H. F. (2011). Obstacles and supports related to the use of educational technologies: The role of technological expertise, gender, and age. Journal of Computing in Higher Education, 23(1), 38-59. doi: 10.1007/s12528-010-9034-3

Legrain, P., Grillet, N., Gernigon, C., \& Lafreniere, M. A. (2015). Integration of Information and communication technology and pupil's motivation in physical education setting. Journal of Teaching in Physical Education, 34(3), 384-401. doi: 10.1123/jtpe.2014-0013

Liu, H., Lin, C. H., \& Zhang, D. (2017). Pedagogical beliefs and attitudes toward information and communication technology: a survey of teachers of English as a foreign language in China. Computer Assisted Language Learning, 30(8), 745-765. doi: 10.1080/09588221.2017.1347572

Liu, Y., \& Szabo, Z. (2009). Teachers' attitudes toward technology integration in schools: A four- year study. Teachers and Teaching: Theory and Practice, 15(1), 5-23. doi: 10.1080/13540600802661295 
Livingstone, S. (2012). Critical reflections on the benefits of ICT in education. Oxford Review of Education, 38(1), 9-24. doi: 10.1080/03054985.2011.577938

Miceli, S., de Palo, V., Monacis, L., Cardaci, M., \& Sinatra, M. (2018). The Italian Version of the Cognitive Style Indicator and its Association with Decision-Making Preferences, Creativity Research Journal, 30 (1), pp. 85-94. doi:10.1080/10400419.2018.1411486

Monacis, L., Finamore, R., Sinatra, M., Bitonto, P. D., Roselli, T., Rossano, V. (2009). Adaptive learning using SCORM compliant resources. Proceedings: DMS 2009 - $15^{\text {th }}$ International Conference on Distributed Multimedia Systems, (pp. 222-227).

Monacis, L., de Palo, V., Sinatra, M., Berzonsky, M.D. (2016). The revised identity style inventory: Factor structure and validity in Italian speaking students, Frontiers in Psychology, 7 (JUN), art. no. 883. doi: $10.3389 /$ fpsyg.2016.00883

Muscara, M., \& Messina, R. (2014). Percezione delle competenze e dell'utilita d'uso delle tecnologie in classe e modelli di formazione dei docenti. Giornale della ricerca educativa, 7(13), 167-181.

Ofulue, C. I. (2011). Survey of Barriers Affecting the Use of Information Communication Technologies (ICTs) among Distance Learners: A Case Study of Nigeria. Turkish Online Journal of Distance Education (TOJDE), 12(3), 142-154.

Prensky, M. (2001). Digital natives, digital immigrants. On the Horizon, 9(1), 1-2.

Prestridge, S. (2012). The beliefs behind the teacher that influences their ICT practices. Computers \& Education, 58(1), 449-458.

Reddy, V. V., \& Srivastava, M. (2003). ICT \& the future of distance education. Turkish Online Journal of Distance Education (TOJDE), 4(4), Retrieved October 19, 2010 from http://tojde.anadolu.edu. tr/tojde12/index.htm

Sang, G., Valcke, M., van Braak, J., Tondeur, J., \& Zhu, C. (2011). Predicting ICT integration into classroom teaching in Chinese primary schools: exploring the complex interplay of teacher-related variables. Journal of Computer Assisted Learning, 27(2), 160-172.

Scherer, R., Tondeur, J., Siddiq, F., \& Baran, E. (2018). The importance of attitudes toward technology for preservice teachers' technological, pedagogical, and content knowledge: Comparing structural equation modeling approaches. Computers in Human Behavior, 80, 67-80. doi: 10.1016/j.chb.2017.11.003

Sinatra, M., Limone, P., \& Contini, P.(2017). Determinants of ICT integration: A path model of teacherrelated factors. Turkish Online Journal of Educational Technology (TOJET), Special Issue, 771-779.

Teo, T. (2011). Factors influencing teachers' intention to use technology: Model development and test. Computer \& Education, 57(4), 2432-2440. doi: 10.1016/j.compedu.2011.06.008

Teo, T., Huang, F., \& Hoi, C. K. W. (2018). Explicating the influences that explain intention to use technology among English teachers in China. Interactive Learning Environments, 26(4), 460-475. doi: $10.1007 / \mathrm{s} 12528-014-9080-3$

Tondeur, J., Aesaert, K., Prestridge, S., \& Consuegra, E. (2018). A multilevel analysis of what matters in the training of pre-service teacher's ICT competencies. Computers and Education, 122, 32-42. doi: 10.1016/j.compedu.2018.03.002

Tondeur, J., van Keer, H., van Braak, J., \& Valcke M. (2008). ICT integration in the classroom: challenging the potential of a school policy. Computers \& Education, 51(1), 212-223. doi: 10.1016/j. compedu.2007.05.003

Ursavaş, Ö. F. (2015). The Influence of Hedonic and Utilitarian Motivations on Teachers Behavioral Intention to Use Tablet PCs. Education \& Science/Egitim ve Bilim, 40(179), 25-43.

van Braak, J., Tondeur, J., \& Valcke, M. (2004). Explaining different types of computer use among primary school teachers. European Journal of Psychology of Education, 19(4), 407-422. doi: 10.1007/ BF03173218

van der Heijden, H. (2004). User acceptance of hedonic information systems. MIS Quarterly, 28(4), 695-704.

Woolley, S. L., Benjamin, W. J. J., \& Woolley, A. W. (2004). Construct validity of a self-report measure of teacher beliefs related to constructivist and traditional approaches to teaching and learning. Educational and Psychological Measurement, 64(2), 319-331. doi: 10.1177/0013164403261 